Ніколюк О.В. доктор економічних наук, професор кафедра менеджменту та логістики

Email: alenavn11@gmail.com ORCID ID: 0000-0002-1665-0361

\section{Седікова I.O.}

доктор економічних наук, професор кафедра менеджменту та логістики

E-mail: irina-sedikova@ukr.net

ORCID ID: 0000-0003-4376-1267

\author{
Клевець М.В. \\ магістрант \\ кафедра менеджменту та логістики \\ Одеська національна академія харчових технологій \\ вул. Канатна 112, м. Одеса, Україна, 65039 \\ E-mail: maryaklevets@gmail.com \\ ORCID ID: 0000-0003-0259-4538
}

\title{
НАЦІОНАЛЬНА БЕЗПЕКА ТА ДЕРЖАВНА ПОЛІТИКА В СФЕРІ РЕАЛІЗАЦІЇ МОРСЬКОГО ПОТЕНЦІАЛУ УКРАЇНИ
}

Географічний потенціал України на глобальному ринку морської торгівлі зовсім не реалізований. Територіальне море (виняткова економічна зона країни) розмір якого трохи менший, ніж сухопутна частина України, змушує з увагою ставитися до державного транспортного й іншого освоєння. Портова галузь відіграє ключову роль у зростанні української економіки. В Україні функціонує мережа паромного сполучення, морських контейнерних ліній. Однак морський фактор розвитку України ще недостатньо осмислений, а вплив на розвиток всього народного господарства - недооцінений. Морський потенціал не використовується достатньою мірою, а для України, економіка якої залежить від рентабельної участі в інтернаціональній спеціалізації праці, виключного значення заслуговує саме ця проблема - проблема розвитку морського потенціалу країни як чинник ії безпеки. Механізм залучення інвестицій у портову галузь включають, але не обмежуються договорами концесії, оренди, угодами про спільну діяльність та іншими видами інвестиційних договорів, що укладаються на основі спеціальних процедур, визначених Законами України.

Ключові слова: національна безпека, морський потенціал, державна політика, морська торгівля, морська культура, інфраструктура.

This work is licensed under a Creative Commons Attribution 4.0 International License http://creativecommons.org/licenses/by/4.0/

Постановка проблеми та її зв'язок з важливими науковими та практичними завданнями. У «Морський доктрині України на період до 2035 року» наголошено, що «особливого значення набуває фактор утвердження України як морської держави, виходячи з їі просторових і геофізичних особливостей, місця та ролі у глобальній та регіональній системі міжнародних відносин» [17]. Однак, на сучасному етапі держава не в змозі в повній мірі забезпечити ефективне використання морського потенціалу, що покликано падінням ВВП національної економіки, геополітичною ситуацією, девальвацією гривні, військовим конфліктом на Сході, пандемією COVID-19. Як відзначено у [16] «морський транспортний комплекс є багатофункціональною структурою, що задовольняє потреби національної економіки у транспортному забезпеченні, сприяє розвитку міжнародної торгівлі та реалізує зобов'язання України як морської держави» [16]. У 2020 році загальний дохід, отриманий від діяльності морських портів України, становив близько 1,7 млрд. доларів \$ (2 \% ВВП країни) [1].
Активна політична, економічна співпраця з СС, проведення постійних консультації, щодо приєднання до НАТО, в умовах ескалації РФ проти України, необхідність прискорення процесу виходу держави 3 довготривалої системної кризи потребують оновлення напрямів розвитку України як морської держави. Необхідність визначення основних напрямів подальшого розвитку з урахуванням забезпечення економічних інтересів України як морської держави та ії безпеки обумовлює актуальність даного дослідження.

Аналіз останніх публікацій по проблемі. Питання розвитку морських портів досліджують зарубіжні та вітчизняні вчені, серед яких: М. Бурмистров, О. Дяченко, С. Мінакова, I. Гришова, І. Грищенко, М. Жилін, С. Ільченко, Є. Ігнатенко, І. Лапкіна, О. Ніколюк, М. Примачов, М. Котлубай C. Grammenos, E. Molnar, W. Suchorzewski та інших. Проблемам національної безпека морської портової галузі присвячені наукові доробки таких дослідників, як: М. Антіпов, А. Вороніна, Я. Жалило, О. Ляшенко, В. Мірошко, І. Покотілов, Н. Татаренко, Т. Цабієва та інші. 
Формулювання цілей дослідження. Метою цієї роботи є дослідження морського потенціалу України та визначення пріоритетних напрямів реалізації національної безпека та державної політики.

Виклад основних результатів та їх обгрунтування. Закон України «Про морські порти в Україні» ст. 1 визначає «морський порт - визначені межами територія та акваторія, обладнані для обслуговування суден і пасажирів, проведення вантажних, транспортних та експедиційних робіт, а також інших пов'язаних 3 цим видів господарської діяльності» [18]. Вони є головною ланкою, яка з'єднує національну виробничо-транспортну інфраструктуру зі світо- вою. Довжина Азово-Чорноморського басейну складає 2,8 тис. км та 72 тис. км² морської економічної зони. На узбережжі Чорного та Азовського морів функціонує 13 морських торговельних портів, загальна довжина причального фронту складає 40 км [17]. Одеська, Миколаївська, Херсонська, Запорізька, Донецька та тимчасово окупована АР Крим мають вихід до Чорного та Азовського морів і займають $\approx 27 \%$ ii території.

За аналітичними даними [19], у 2020 році 5 найбільших морських портів обробили 97 млн. тон вантажів (рис. 1).

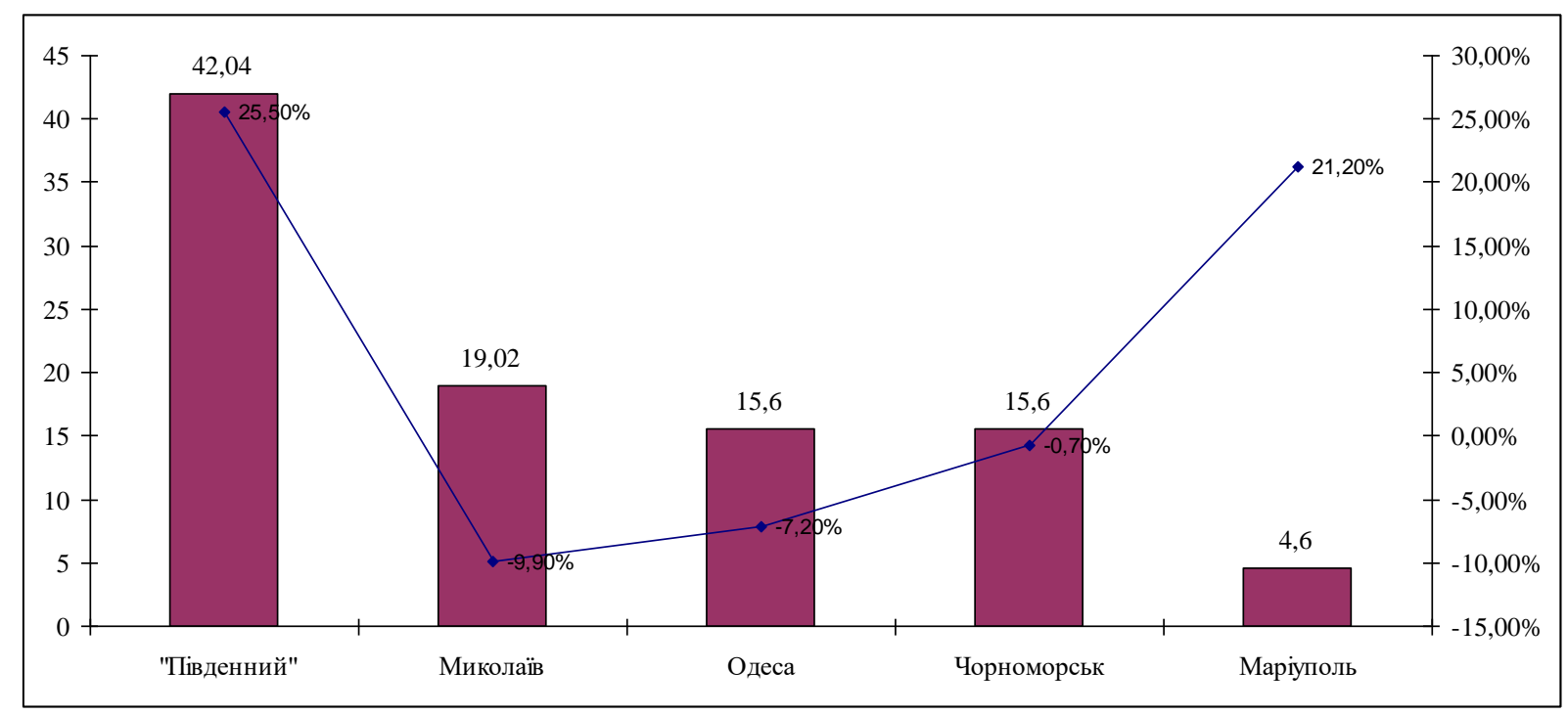

Рис. 1. Перевалка вантажів у портах України у 2020 р.*

* розроблено авторами на основі [19]

Динамічно збільшують перевалку вантажів порти Ольвія та Бердянськ до 3 млн. т (+ 52 \%) та 1,5 млн. т (33 \%) відповідно відносно показника 2019 р. [19]. Для інтегрованого розвитку портової інфраструктури України, створення механізму залучення інвестицій у 2013 році було створено Адміністрацію морських портів України (АМПУ), що має стратегічне значення для економіки і безпеки України. Відповідно до місії АМПУ розробила плани розвитку 13-ти морських портів, які зараз перебувають на різних стадіях реалізації.

У рамках цих планів АМПУ працює над новим екологічним проектом «Зелені Українські порти». Окрім екологічних ініціатив, АМПУ також хоче використати потенціал існуючих можливостей перевезення вантажів у басейні Чорного моря. В даний час влада працює над масштабним інфраструктурним проектом зі створення одного 3 найглибших портів у Чорному морі, а саме - Порту «Южний». Проект, який планується завершити через два роки, збільшить глибину порту до 21 метрів, що дозволить приймати судна «Сареsize» і повністю використовувати можливості Босфорської протоки для доставки вантажів через українські порти. На Босфорі існує обмеження на прохід суден певної довжини і як наслідок, є те, що контейнери з 20000 TEU не можуть пройти через Босфор та потрапити до портів України. Порти України забезпечують перевалку понад 40 \% міжнародних вантажів, які прямують до країни або виходять за іï межі. Найбільший потенціал портів полягає в перевантаженні сільськогосподарської продукції, залізорудної сировини та металевих виробів.

Прогнозуючи майбутнє українських портів можна зазначити, що в середньостроковій перспективі однією з головних тенденцій в портовій галузі України буде вихід держави із стивідорного бізнесу та активна передача майна державних стивідорів [6, 13]. Це дозволить залучити стратегічних інвесторів у розвиток портової інфраструктури та сприятиме впровадженню інноваційних технологій, та залученню нових вантажних потоків.

Для розвитку Україна має бути конкурентоспроможною не лише в басейні ЧорноморськоАзовського регіону, але і в усьому світі, щоб міжнародні судноплавні та контейнерні лінії включали українські порти у свої логістичні мережі. Тому на початку 2018 року портові збори були знижені на 20 \%. Крім того, такі проекти, як днопоглиблення, моде- 
рнізація причальної та термінальної інфраструктури, здійснюються з метою розкриття потенціалу морських портів України. До кінця 2021 року АМПУ планує довести глибини в портах Бердянськ та Маріуполь до паспортних глибин. Також у Маріуполі триває інвестиційний проект щодо реконструкції причалу № 4 та будівництва нового зернового терміналу [7, $15]$.

Сучасне суспільство формує потужний макроекономічний попит на розвиток транспортної інфраструктури, як найважливішого базового фактора стійкого і динамічного зростання української економіки, посилення іiї позицій на внутрішній і міжнародній арені. У цих умовах зростає роль морської безпеки як елемента політичного порядку. Зазначений аспект національної безпеки повинен враховувати, при стратегічному плануванні державної політики, багато економічних, екологічних, соціальних факторів.

У рамках міжнародного політичного регулювання діяльності на морі, міжнародні інституції, національні стейкхолдери виступають гарантами забезпечення морської безпеки, які здатні надавати регулюючий та контролюючий вплив на поведінку окремих держав, судновласників в інтересах міжнародного морського співтовариства.

Розробка стратегії національної безпеки в контексті безпеки морського судноплавства грунтується на ситуаційному підході, який не відповідає існуючим загрозам. В якості нової методологічної основи заходів щодо посилення морської безпеки запропоновано використовувати системносинергетичний підхід, а в якості базової наукової теорії - теорію ризиків, яка дозволяє передбачати можливі загрози на ранніх стадіях їх виникнення та розробляти превентивні заходи. При цьому в розробці заходів національної безпеки політико-соціальна складова повинна бути посилена.

Держави розробляють стратегії національної безпеки в сфері транспортних перевезень, орієнтуючись на міжнародні правові норми, в яких питанням морської безпеки, порятунку людей, вантажів при морських аваріях приділяється валика увага.

Під міжнародним політичним порядком діяльності на морі, розуміємо політичний порядок, який склався між усіма учасниками морської діяльності країнами світу, які умовно іменуються міжнародним морським співтовариством. Відносини між членами міжнародного морського співтовариства i, отже, міжнародний порядок діяльності на море визначаються взаємодією різних чинників, найбільш важливу роль, серед яких відіграє співвідношення сукупних політичних, соціально-економічних ресурсів, задіяних в організації та здійсненні морського судноплавства та діяльності портових підприємств, державних структур.

Геополітичні фактори морської безпеки пов'язані з усвідомленням необхідності консолідації світової спільноти перед спільними загрозами, протистояти яким ефективно можна лише об'єднаними зусиллями. 3 політичної точки зору, національна безпека розглядається нами як частина суспільного бла- га, а їі рівень визначається ресурсами, які країна без шкоди для життєвого рівня свого населення може на неї виділити.

Аналізуючи різні державні акти, пов'язані 3 розвитком судноплавства і проблематикою національної безпеки, автори дослідження роблять висновок: розглядаючи зміст, значення концептуальних положень, 3 точки зору існуючого політичного порядку, можна однозначно стверджувати - участь держави в забезпечені морської транспортної безпеки має стратегічне значення, ця функція не може бути перекладена тільки на господарюючі суб'єкти.

3 точки зору авторів, подальше вдосконалення законодавства в сфері безпеки має здійснюватися шляхом створення єдиної системи правового регулювання всього спектра відносин, що складаються в даній області. 3 цією метою необхідно визначити пріоритети, перспективи законодавчого забезпечення національної безпеки, удосконалити систему експертних оцінок прийнятих нормативних правових актів.

У площині дослідження авторами пропонується розглянути політичні аспекти культури безпеки на морі та соціально-політичні ризики як невід'ємні компоненти національної безпеки. Як відомо, поняття культури досить ємне і під ним розуміється образ життя людей або спільноти в певному регіоні в певний період часу.

Культура безпеки на морі - це такий набір характеристик і особливостей діяльності організацій та поведінки окремих осіб, які беруть участь в створенні та експлуатації морських суден (портових споруд), який приділяє увагу, проблемам безпеки, що визначається ії соціально-політичною та економічною значимістю.

Культура безпеки на морі має на увазі, щоб усіма акторами, причетними до діяльності на морі, обов'язки, важливі для забезпечення безпеки, виконувалися точно, осмислене, на основі особистих знань, здорового глузду та відповідальності. Мова йде про збереження людського життя, суден, вантажу, а також захисту навколишнього середовища. Всі вищевказані складові культури безпеки входять в сферу національної безпеки. В першу чергу, мова йде про запобігання аваріям через впровадження культури безпеки з усвідомленням потреби в «культурі виживання», тобто виконання дій, націлених на охорону людського життя, обмеження шкоди від наслідків аварій.

Найпотужнішим фактором подальшої глобалізації суспільства в найближчі десятиліття може стати усвідомлення необхідності об'єднання зусиль світової спільноти для боротьби з глобальними загрозами екологічного характеру, в тому числі що виникають в результаті діяльності людей в світовому океані. Тут на перший план висуваються такі проблеми, як безпрецедентне забруднення води, грунту, дна світового океану, повітря промисловими відходами, знищення флори та фауни планети в результаті господарської діяльності людини.

Висновки та перспективи подальших досліджень. Авторами проаналізовано основні міжнаро- 
дні документи, що стосуються безпеки мореплавання, при цьому робиться висновок про те, що Україні належить завершити гармонізацію свого законодавства відповідно до змін міжнародних норм, що стосуються морської безпеки. Розробка тематики проблем національної безпеки повинна грунтуватися не на ситуативно-галузевому підході, а на використанні системносинергетичної методології, в основі якої прогнозний варіант розвитку соціально-політичних подій.

Екологічні ризики породжують певний стан масового суспільної свідомості - екологічний стрес, що виникає в процесі поступової або раптової загрози природі та житті людини. Відсутність в регіоні Чор- ного моря ефективно діючих неурядових екологічних організацій призводить до появи проектів, екологічні наслідки яких важко прогнозовані.

Аналіз морського потенціалу України дозволив сформувати основні пріоритети: збереження i подальше нарощування обсягів транзитної торгівлі через порти України; створення мережі спеціалізованих припортових комплексів обробки транзитних вантажів; забезпечення збалансованості портової інфраструктури. Перспективною формою організації вільних територій повинні стати зони інфраструктурного розвитку портів.

\section{Література}

1. Ніколюк О., Донець Л., Левчук Ю. Державне управління інноваційного розвитку морських портів України // Проблеми і перспективи економіки та управління. 2019. № 4 (20). С. 137-146

2. Винников В. В. Проблемы комплексности развития морского транспорта Украины: монографія. Одесса: Феникс, 2005. 350 с.

3. Жихарева, В.В. Теория и практика инвестиционной деятельности судоходных компаний: монография. Одесса: ИПРЭЭИ НАН Украины, 2010. 480 с.

4. Маркс К. Капитал: в 3 т. Т.1 Критика политической экономии / К. Маркс; пер. П. Клюкина. М.: Манн, Иванов и Фербер, 2014. 1200 с.

5. Миюсов М. В., Примачев Н. Т. Стратегия позиционирования национального морского в глобальном транспортном рынке / под общ. ред. Н. Т. Примачева. Одесса: Автограф, 2006. 244 с.

6. Сайт Державного Комітету Статистики України: [Веб-сайт]. URL: http://www.ukrstat.gov.ua. (дата звернення: 2.02.2021).

7. Доктрина від 07.10.2009 № 1307 // Про затвердження Морської доктрини України на період до 2035 року: [веб-сайт]. Київ. URL: https://zakon.rada.gov.ua/laws/show/1307-2009-\%D0\%BF\#Tехt (дата звернення: 10.02.2021).

8. Рудь I. Транзитний морський потенціал України: сучасні реалії та перспективи. Україна: події, факти, коментарі: [веб-сайт]. 2016. URL: http://nbuviap.gov.ua/images/ukraine/2016/ukr5.pdf (дата звернення: 1.02.2021).

9. Желтухін С., Горьова О., Чернишук П. Портові збори: державний бізнес чи підтримка експорту? // Юридична Газета. 2017. №23 (573). С. 19

10. Желтухін С., Горьова О., Чернишук П. Всеукраїнське щотижневе професійне видання Кодекс торговельного мореплавства: в очікуванні змін // Юридична Газета. 2017. №25 (575). С.19

11. Interview: Ukrainian Ports Aim to Become Deeper and Greener: Offshore energy: [Веб-сайт]. Одеса, 2018. URL: https://www.offshore-energy.biz/interview-ukrainian-ports-aim-to-become-deeper-and-greener/ (дата звернення: 8.02.2021).

12. Ukrainian seaport: Balancing between economy and geopolitics: [Web-site]. URL: https://112.international/article/sea-ports-of-ukraine-balancing-between-economy-and-geopolitics-29666.html (дата звернення: 8.02.2021).

13. Гришова І., Гришова Р. Перспективи розвитку освіти, науки і бізнесу в глобальному середовищі // Державна політика стійкого розвитку в контексті циркулярної моделі економіки: матеріали VIII Міжнародної наук.-практ. конф., Тернопіль, 23 жовтня 2020 р. Тернопіль: ФОП Осадча Ю. В., 2020. С. 45-47.

14. Гришова І.Ю., Дяченко О.П. Державна політика розвитку морських портів України в контексті розвитку міжнародних транспортних коридорів // Інвестиції: практика та досвід. 2019. № 13. C. 5-11. DOI: 10.32702/2306-6814.2019.13.5.

15. Гришова І.Ю., Дяченко О.П. Державна інвестиційна політика розвитку морських портів України // Інвестиції: практика та досвід. 2019. № 11. С. 5-11.

16. Стратегія морських портів України до 2038 року. Міністерство інфраструктури України: веб-сайт. URL:http://surl.li/qfpz (дата звернення: 08.02.2021).

17. Морська доктрина України на період до 2035 року: Постанова Кабінету Міністрів України за станом на 18.12.2018p. URL: https://zakon.rada.gov.ua/laws/show/1307-2009-\%D0\%BF\#Tеxt (дата звернення: 08.02.2021).

18. Про морські порти України: Закон України за станом на 14.01.2020p. / Верховна Рада України. URL: https://zakon.rada.gov.ua/laws/show/4709-17\#Text (дата звернення: 08.02.2021).

19. Топ-5 портів України за 8 місяців обробили 97 мільйонів тонн вантажів. Економічна правда: [Вебсайт]. URL: https://www.epravda.com.ua/news/2020/09/4/664743/(дата звернення: 08.02.2021).

Стаття надійшла 11.02.2021

Стаття прийнята до друку 25.02.2021

Доступно в мережі Internet 18.04.21 


\section{Nikoliuk 0. \\ Doctor of Economics, Professor \\ Department of Management and Logistics \\ E-mail: alenavn11@gmail.com \\ ORCID ID: 0000-0002-1665-0361

\author{
Sedikova I. \\ Doctor of Economics, Professor \\ Department of Management and Logistics \\ E-mail: irina-sedikova@ukr.net \\ ORCID ID: 0000-0003-4376-1267
}

\author{
Klevets $\mathrm{M}$. \\ Undergraduate \\ Department of Management and Logistics \\ Odessa National Academy of Food Technologies \\ Kanatna str., 112 Odesa, Ukraine, 65039 \\ E-mail: maryaklevets@gmail.com \\ ORCID ID: 0000-0003-0259-4538
}

\title{
NATIONAL SECURITY AND STATE POLICY IN THE FIELD OF REALIZATION OF UKRAINE'S MARITIME POTENTIAL
}

The geographic potential of Ukraine in the global maritime trade market has not been realized. The maritime potential of Ukraine has been studied and the priority directions for the implementation of national security and state policy have been identified.

It has been noted that modern society forms a powerful macroeconomic demand for the development of transport infrastructure, as the most important basic factor for sustainable and dynamic growth of the Ukrainian economy, strengthening its position in the domestic and international arena. In these conditions, the role of maritime security as an element of the political order is growing. This aspect of national security should be taken into account in the strategic planning of state policy, many economic, environmental, social factors.

It has been proved that within the framework of international political regulation of activities at sea, international institutions, national stakeholders act as guarantors of maritime security, exerting a regulatory and controlling influence on the behavior of individual states, ship owners in the interests of the international maritime community.

The authors have analyzed the main international documents related to the safety of navigation, concluded that Ukraine needs to complete the harmonization of its legislation in accordance with international maritime safety standards. The development of topics for national security problems should not be based on a situational-sectoral approach, but on the use of a systemic-synergetic methodology, which is based on a predictive version of the development of socio-political events.

Environmental risks give rise to a certain state of mass public consciousness - environmental stress arising in the process of a gradual or sudden threat to nature and human life. The absence of effective nongovernmental environmental organizations in the Black Sea region leads to the emergence of projects, the environmental consequences of which are difficult to predict.

Analysis of Ukraine's maritime potential made it possible to formulate the main priorities: maintaining and further increasing the volume of transit trade through the ports of Ukraine; creation of a network of specialized port complexes for handling transit cargo; ensuring the balance of the port infrastructure. Zones of infrastructure development of ports should become a promising form of organizing free territories.

Key words: national security, maritime potential, state policy, maritime trade, maritime culture, infrastructure.

\section{References}

1. Nikoliuk, O., Donets, L., \& Levchuk, Yu. (2019). Derzhavne upravlinnia innovatsiinoho rozvytku morskykh portiv Ukrainy. Problemy i perspektyvy ekonomiky ta upravlinnia, 4(20), 137-146.

2. Vinnikov, V. V. (2005). Problemyi kompleksnosti razvitiya morskogo transporta Ukrainyi. Odessa: Feniks.

3. Zhihareva, V.V. (2010). Teoriya i praktika investitsionnoi deyatelnosti sudohodnyih kompanii. Odessa: IPREEI NAN Ukrainy.

4. Marks, K. (2014). Kapital. (P. Klyukina, Trans.) (Vol. 1 Kritika politicheskoy ekonomii). Moscow: Mann, Ivanov i Ferber.

5. Miyusov, M. V., \& Primachev, N. T. (2006). Strategiya pozitsionirovaniya natsionalnogo morskogo $v$ globalnom transportnom ryinke. (N. T. Primacheva, Ed.). Odessa: Avtograf.
6. Say̆t
Derzhavnoho
Komitetu
Statystyky
Ukraïny.
Retrieved
February
02, 2021, from 
http://www.ukrstat.gov.ua

7. Doktryna vid 07.10.2009 № 1307 Pro zatverdzhennia Morskoi doktryny Ukrainy na period do 2035 roku. Retrieved February 10, 2021, from https://zakon.rada.gov.ua/laws/show/1307-2009-\%D0\%BF\#Text

8. Rud, I. (2016). Tranzytnyi morskyi potentsial Ukrainy: suchasni realii ta perspektyvy. Ukraina: podii, fakty, komentari. Retrieved February 01, 2021, from http://nbuviap.gov.ua/images/ukraine/2016/ukr5.pdf

9. Zheltukhin, Ye., Horova, O., \& Chernyshuk, P. (2017). Portovi zbory: derzhavnyi biznes chy pidtrymka eksportu? Yurydychna Hazeta, (23(573)).

10. Zheltukhin, Ye., Horova, O., \& Chernyshuk, P. (2017). Vseukrainske shchotyzhneve profesiine vydannia Kodeks torhovelnoho moreplavstva: v ochikuvanni zmin. Yurydychna Hazeta, (25(575)), 19.

11. Interview: Ukrainian Ports Aim to Become Deeper and Greener. (2018). Offshore energy. other. Retrieved February 08, 2021, from https://www.offshore-energy.biz/interview-ukrainian-ports-aim-to-become-deeper-andgreener/.

12. Ukrainian seaport: Balancing between economy and geopolitics. (2018). Retrieved February 08, 2021, from https://112.international/article/sea-ports-of-ukraine-balancing-between-economy-and-geopolitics-29666.html

13. Hryshova, I., \& Hryshova, R. (2020). Perspektyvy rozvytku osvity, nauky i biznesu v hlobalnomu seredovyshchi. materialy VIII Mizhnarodnoi nauk.-prakt. konf. In Derzhavna polityka stiikoho rozvytku $v$ konteksti tsyrkuliarnoi modeli ekonomiky (pp. 45-47). Ternopil; FOP Osadcha Yu. V.

14. Hryshova, I. Yu., \& Diachenko, O.P. (2019). Derzhavna polityka rozvytku morskykh portiv Ukrainy v konteksti rozvytku mizhnarodnykh transportnykh korydoriv. Investytsii: praktyka ta dosvid, (13), 5-11. doi: 10.32702/2306-6814.2019.13.5.

15. Hryshova, I. Yu., \& Diachenko, O. P. (2019). Derzhavna investytsiina polityka rozvytku morskykh portiv Ukrainy. Investytsii: praktyka ta dosvid, (11), 5-11.

16. Stratehiia morskykh portiv Ukrainy do 2038 roku. Ministerstvo infrastruktury Ukrainy. Retrieved February 08, 2021, from http://surl.li/qfpz

17. Morska doktryna Ukrainy na period do 2035 roku: Postanova Kabinetu Ministriv Ukrainy za stanom na 18.12.2018 r. Retrieved February 08, 2021, from https://zakon.rada.gov.ua/laws/show/1307-2009-\%D0\%BF\#Text

18. Pro morski porty Ukrainy: Zakon Ukrainy za stanom na 14.01.2020r. Verkhovna Rada Ukrainy. Retrieved February 08, 2021, from https://zakon.rada.gov.ua/laws/show/4709-17\#Text

19. Top-5 portiv Ukrainy za 8 misiatsiv obrobyly 97 milioniv tonn vantazhiv. Ekonomichna pravda. Retrieved February 08, 2021, from https://www.epravda.com.ua/news/2020/09/4/664743/

Received 11 February 2021

Approved 25 February 2021

Available in Internet 18.04.21

Цитування згідно ДСТУ 8302:2015

Ніколюк О.В., Седікова І.О., Клевець М.В. Національна безпека та державна політика в сфері реалізації морського потенціалу України // Економіка харчової промисловості. 2021. Т.13, вип. 1. С.90-95.

Cite as APA style citation

Nikoliuk, O., Sedikova, I, \& Klevets, M. (2021). National security and state policy in the field of realization of Ukraine's maritime potential. Food Industry Economics, 13(1), 90-95. 